\title{
HARMONIZING POTENTIAL OF EQUITY-BASED CROWDFUNDING REGULATION
}

\author{
Jan Mazur \\ Comenius University in Bratislava, Faculty of Law
}

\begin{abstract}
Equity-based crowdfunding shows promising potential for funding the micro, small and medium sized enterprises. So far, only several countries have adopted a specific regulation of crowdfunding, while there is no crowdfunding-specific regulation (harmonization) on the EU level. As we already observe diverging tendencies of the crowdfunding market and its regulation in respective member states, there seems to be an untapped potential of harmonizing certain aspects of capital markets law, such as Prospectus Directive. We will assess the needs of the crowdfunding market and reflect them against the Prospectus Directive and its implementation in selected member states. The assessment serves as a basis for discussion on harmonization potential.
\end{abstract}

Key words: crowdfunding, harmonization, capital markets

\section{INTRODUCTION}

The article aims to describe the main barriers and obstacles to proliferation of equity-based crowdfunding for small and medium enterprises (SMEs) in relation to the Prospectus Directive. As was acknowledged repeatedly by the EU, SMEs play a crucial role in European economy. ${ }^{1}$ However their access to finance remains limited mostly to banking finance and self-finance. Innovative means of finance, such as crowdfunding, appear to offer another viable conduit for securing finance, especially for micro and small SMEs. Yet the capital markets regulation currently presents a significant barrier to mainstream crowdfunding takeoff, especially crowdinvesting, since the regulation has not been adopted to regulate crowdinvesting at the first place. On-going academic endeavors continue to map regulatory implications of the EU capital markets regulation on crowdfunding market and its further development. The ambition of this article is to contribute to this debate and provide ideas on harmonization potential of prospectus requirements.

The structure of the article is the following. We start with the describing the importance and financing of SMEs based on the cumulated academic and other knowledge and evidence. Second, we introduce the basic definitions, elements and taxonomy of crowdfunding with a special focus on the equity-based crowdfunding. Finally, we sum up the identified barriers and obstacles of equitybased crowdfunding.

1 See: EUROPEAN COMMISSION: Communication From The Commission An action plan to improve access to finance for SMEs $/ *$ COM/2011/0870 final */, or EUROPEAN COMMISSION: Communication from the Commission to the Council, the European Parliament, the European Economic and Social Committee and the Committee of the Regions “Think Small First” - A “Small Business Act” for Europe $\{$ SEC(2008) 2101\} \{SEC(2008) 2102\}/* COM/2008/0394 final*/. 


\section{EQUITY-BASED CROWDFUNDING AND SMES}

\subsection{Financing SMEs}

It has long been established that SMEs play a crucial role in economy ${ }^{2}$. SMEs constitute $99,8 \%$ of all businesses in non-financial business sector of the EU; they employed almost 90 million employees in 2014 (67\% of total employment). SMEs also contributed significantly to the employment growth - 71,4\% of the increase in employment in the non-financial sector in 2014 is attributed to SMEs. Moreover, in 2014 micro SMEs accounted for 29,2\% of total employment, whereas small SMEs for $20,4 \%$ and medium SMEs for $17,3 \%$ of total employment respectively. ${ }^{3}$

SMEs are considered the main drive behind the job creation; they are the main vehicles for the creation and dissemination of innovation and are crucial in achieving development objectives. ${ }^{4}$ Moreover, SMEs tend to have strong capacity for exploiting strong synergies. However, SMEs also face specific factors that inhibit their development and growth, such as limited access to finance, poor managerial skills, lack of training opportunities, or high input costs. Many of these factors could be attributed to the limited access to finance in general. These factors are even more exaggerated when it comes to microenterprises, which also face the following challenges: (i) low net profits limiting their ability to self-finance growth; (ii) weak financial structures; or (iii) lack of relationships with the banking system limiting their access to the (only) viable source of finance. ${ }^{5}$ EC DG Growth and ECB's joint 2014 survey of financing conditions faced by SMEs further states the six major problems faced by SMEs (self-reported): (i) finding customers; (ii) competition; (iii) access to finance (though having improving tendency); (iv) costs of production or labor; (v) availability of skilled staff or experienced managers; and (vi) regulation. ${ }^{6}$

\subsection{Crowdfunding}

In general, crowdfunding usually refers to an open call to the public to raise funds for a specific project. ${ }^{7}$ It is a promising way of financing various civic projects and endeavors, scientific projects, politics, creative industries, but also SMEs, micro and small enterprises in particular. ${ }^{8}$ A very broad

2 An SME (micro, small and medium-sized enterprises) is defined along two thresholds: (i) fewer than 250 employees, and (ii) an annual turnover not exceeding 50 million EUR, and/or an annual balance sheet total not exceeding 43 million EUR. EUROPEAN COMMISSION: Commission Recommendation of 6 May 2003 concerning the definition of micro, small and medium-sized enterprises (Text with EEA relevance) (notified under document number C(2003) 1422). OJ L $124,20.5 .2003$, p. 36-41.

3 MULLER, P. - CALIANDRO, C. - GAGLIARDI, D. - MARZOCCHI, C.: Annual report on European SMEs 2014/2015. Brussels: European Commission, 2015, p. 4-8.

4 EDWARDS T. - DELBRIDGE R. - MUNDAY, M.: Understanding innovation in small and medium-sized enterprises: a process manifest. In: Technovation, 2005, 25, 10, pp. 1119-1127.

5 The section is drawn from: PES, G. N. - PORRETTA, P.: Microfinance, EU Structural Funds and Capacity Building for Managing Authorities. A Comparative Analysis of European Convergence Regions. Houndmills: Palgrave Macmillan, 2015, p. 11-23.

6 Available at: <https://www.ecb.europa.eu/stats/money/surveys/sme/html/index.en.html $>$.

7 EUROPEAN COMMISSION: Communication From The Commission To The European Parliament, The Council, The European Economic And Social Committee And The Committee Of The Regions Unleashing the potential of Crowdfunding in the European Union $/ *$ COM/2014/0172 final $\%$.

8 See for instance: civic and non-profit projects, Generosity.com, creative industries, Kickstarter.com, art, Arthena.com, politics, Crowdpac.com, scientific projects, SMEs, Seedrs.com, Symbid.com. 
approach to crowdfunding allows us to understand crowdfunding as enabled by the internet/web 2.0. ${ }^{9}$ Specifically, the internet enabled huge amounts of people to participate on creative processes of others, get engaged with creators and support them financially while maintaining very low transaction costs for the participants. ESMA defines crowdfunding as "a means of raising finance for projects from 'the crowd' often by means of an internet-based platform through which project owners 'pitch' their idea to potential backers, who are typically not professional investors". ${ }^{10}$

Crowdfunding has developed into many forms: from pure donation-based, through more elaborate reward-based, to complex investment-based crowdfunding. Donation-based crowdfunding represents one of the earliest forms of crowdfunding, which allows a large number of people donate money for a certain cause or project without receiving anything (material) in return. On the other hand, reward-based crowdfunding offers an opportunity to finance a production or project in return for a material reward, typically a product, work of art, or service. Finally, investment-based crowdfunding usually takes four forms: (i) crowdlending (peer-to-peer lending), (ii) equity-based crowdfunding, (iii) profit-sharing crowdfunding, and (iv) invoice trading crowdfunding. Naturally, the regulatory requirements will be most manifested in the investment-based crowdfunding, which creates a more complex legal relationship between project owners and backers.

The volume of crowdfunding market has been increasing for the past years since its inception. ${ }^{11}$ The total global crowdfunding volume is estimated at 34 billion USD in 2015, whereas peer-to-peer lending amounted to 25 billion USD, reward- and donation-based crowdfunding to 5,5 billion USD and equity-based crowdfunding to 2,5 billion USD. The EU crowdfunding market shows significant volumes as well, yet its volumes are still considered below its full potential: (i) equity-based crowdfunding amounted to over 422 million EUR of raised capital with average campaign of over 0,5 million EUR raised funds, performed on 60 EU-based platforms via 836 campaigns, and (ii) peerto-peer loans amounted to over 3,2 billion EUR with an average campaign of 15.688 EUR raised funds, performed on 77 EU-based platforms via 204.575 campaigns. ${ }^{12}$ The crowdfunding market is expected to continue to grow exponentially for several years and eventually become a significant, yet complimentary source of finance to traditional sources. ${ }^{13}$

\subsection{Regulatory issues}

In relation to the above mentioned definitions of crowdfunding, academia understands the terms as "a collective effort by people who network and pool their money together, usually via the internet, in order to invest in and support efforts initiated by other people or organization"14, or as a "pooling

9 For history of crowdfunding see: FREEDMAN, D. M. - NUTTING, M. R.: A Brief History of Crowdfunding. Including Rewards, Donation, Debt, and Equity Platforms in the USA. 2015. Available at: <http://www.freedman-chicago.com/ ec4i/History-of-Crowdfunding.pdf>

10 ESMA. „Opinion. Investment-based crowdfunding. ESMA/2014/1378.” 2014.

11 See: <http://crowdexpert.com/crowdfunding-industry-statistics/>

12 EUROPEAN COMMISSION: Commission Staff Working Document: Crowdfunding in the EU Capital Markets Union, Brussels, SWD(2016) 154 final, p. 10.

13 Although, peer-to-peer lending appears to have more disruptive potential on traditional sources of finance, especially on non-bankable market segments.

14 ORDANINI, A. - MICELI, L. - PIZZETTI, M. - PARASURAMAN, A.: Crowd-funding. Transforming customers into investors through innovative service platforms. In: Journal of Service Management, 2015, 22, 4, pp. 443-470. DOI $10.1108 / 09564231111155079$. 
money from a group of people, typically comprised of very small individual contribution, to support another's effort to accomplish a specific goal". ${ }^{15}$ Hence we can draw certain common features of crowdfunding, which will be relevant for regulatory implications:

- backers are usually a large amount of rather unprofessional people/investors (in contrast with professional investors on capital markets);

- the internet platform provides the third party intermediary service (transaction management) and infrastructure (marketplace) in return for a fee;

- in crowdinvesting, further exercise of rights is required: voting rights, distribution of gains/profits/interests;

- in crowdinvesting, campaigns are of rather low volume in contrast with traditional capital market typically in 100.000s EUR up to several million;

- project owners raising funds are normally unlisted, micro and small SMEs, startups.

Usual business setup of crowdfunding involves three main actors: ${ }^{16}$ (i) project owners or creators who propose, market and run their projects; under crowdinvesting, this actor typically issues an instrument (e.g. security); (ii) funders or investors (also known as backers) who fund or invest into projects or companies; and (iii) crowdfunding platforms, which are virtual spaces for creators and funders to exchange resources, and provide transaction and post-transaction services. ${ }^{17}$ Crowdfunding platforms typically operate as intermediaries in return for a share on raised funds. This setup may be prone to certain conflicts of interest and moral hazard, where a platform may advertise a project, which lacks the quality, without performing due diligence, because it is motivated by the fees it charges. Moreover, crowdfunding may be prone to frauds, especially when platforms either fail to perform quality due diligence, or do not perform any as their policy. The unprofessional character of backers/investors typically translates into the lack of investment skills, manifested in behaviors, such as failure to perform basic investor's diligence, failure to understand and assess multiple and typically high risks attached to the investment, failure to diversify portfolio, or even improper use of leverage. ${ }^{18}$ Also, as any human behavior, crowdfunding is prone to herding behavior of backers and investors. ${ }^{19}$

The main regulatory issues related to crowdfunding are clustered around the information asymmetry and herding behavior. In fact, the ambition of regulator in regulating crowdfunding may be understood as finding the right balance between encouraging crowdfunding investments to fulfill its potential while maintaining investors' protection. As of now, it is generally understood that there are no known systemic regulatory issues related to crowdfunding, unlike to the capital markets and banking industries.

15 GRIFFIN, Z.: Crowdfunding. Fleecing the American masses. In: Case Western Reserve Journal of Law, Technology \& the Internet, 2012. Available at: <http://ssrn.com/abstract $=2030001>$.

16 DE BUYSERE, K. - GAJDA, O. - KLEVERLAAN, R. - MAROM, D.: A Framework for European Crowdfunding, 2012.

17 AGRAWAL, A. - CATALINI, C. - GOLDFARB, A.: Entrepreneurial Finance and the Flat-World Hypothesis. Evidence from Crowd-Funding Entrepreneurs in the Arts, 2010. Working papers.

18 Risks are in general higher in investment-based crowdfunding forms and typically involve risk of capital loss, risk of dilution, inability to liquidate an investment, late or no share on profit/dividend payments, limited access to information, limited access to execute voting rights, etc. Some risks are exemplified by ESMA. „Opinion. Investment-based crowdfunding. ESMA/2014/1378." 2014.

19 For a wider discussion on when crowds fail and when they succeed see: SUNSTEIN, C. R. - HASTIE, R.: Wiser: Getting Beyond Groupthink to Make Groups Smarter. N.p.: Harvard Business Review, 2014. 


\subsection{Barriers and obstacles}

Drawing from above, we may sum up the barriers and obstacles inhibiting the growth-enabling regulatory setup of crowdfunding as following. First, it is understood that there is still no commonly accepted taxonomy of crowdfunding, which is a result of the fact that crowdfunding is a relatively new phenomenon and the academic and policy knowledge is still being established. There is no common EU-wide and EU-based approach to regulation of crowdfunding. This fact is rather insignificant in donation- and reward-based crowdfunding markets, but becomes significant in investment-based crowdfunding market. As a result, certain forms of crowdinvesting cannot benefit from the single passport rule established by the MiFID. ${ }^{20}$ Moreover, regulatory minimum may be beneficial in order to create confidence towards the new industry and level playing field for the market participants. There is also lack of information sharing and data gathering on respective forms of crowdfunding, which disallows structured action by policy makers. ${ }^{21}$

In general it can be argued, along with ESMA, that "EU financial services rules were not designed with the industry in mind." 22 Contemporary regulation of crowdfunding appears to be a regulatory by-product, rather than a structured regulatory and policy response. Unclear regulatory implications and interpretations lead to different level playing fields within the EU. ESMA mentions among the key components of appropriate regulatory response the following features:

- proportional capital requirements or similar mechanisms for safeguarding operational continuity. This point is also very dependent on the operational business models of respective platforms;

- a mechanism to make sure that investment opportunities are proposed to appropriate investors;

- a mechanism of proper risk informing and warning;

- proper segregation of the client assets;

- mechanisms to identify and mitigate conflicts of interest;

- certainty about the nature and extent of the platform's duties towards clients.

It is worth mentioning that there are regulatory issues not related directly to crowdinvesting platforms, but to project owners or companies that market their projects on these platforms. The main issues are related to various corporate law regimes that inhibit or strengthen their crowdinvesting options, but also to higher costs attached to transparency requirements in relation to the Prospectus Directive.

\subsection{Prospectus regimes and harmonizing potential}

Crowdfunding is positioned among the policy areas, where the European Commission is active in terms of sharing good policies and best practices. Also, ESMA states that "while risks to investors could be mitigated by action at national level, such action will not address the scalability issues." 23 Moreover, as is evidenced by the EC Communication $49 \%$ of the respondents called on the EU to

20 EUROPEAN COMMISSION: Directive 2004/39/EC of the European Parliament and of the Council of 21 April 2004 on markets in financial instruments amending Council Directives 85/611/EEC and 93/6/EEC and Directive 2000/12/EC of the European Parliament and of the Council and repealing Council Directive 93/22/EEC (further as „MiFID“).

21 EUROPEAN COMMISSION: Commission Staff Working Document: Crowdfunding in the EU Capital Markets Union, Brussels, SWD(2016) 154 final. 6.

22 ESMA. „Opinion. Investment-based crowdfunding. ESMA/2014/1378.” 2014, p. 4.

23 ESMA. „Opinion. Investment-based crowdfunding. ESMA/2014/1378.” 2014, p. 5. 
promote the single market for financial return crowdfunding and 51\% saw a need for EU action to secure a proper investor protection for crowdinvesting. ${ }^{24}$

Harmonizing potential exists on various issues mentioned above. We focus on the potential for further harmonization of the Prospectus Directive 2003/71/EC ${ }^{25}$. PD puts forward requirements of prospectus publication before the offer of securities to the public is made or the admission to trading on regulated markets takes place. PD article 1(1) "harmonizes requirements for the drawing up, approval and distribution of the prospectus to be published when securities are offered to the public or admitted to trading on a regulated market." Whereas the obligation to publish a prospectus is an important element of the EU capital markets and the EU regime offers passporting benefits, it may be related to relatively huge costs on the account of especially smaller SMEs.

First of all, it is important to take into account that PD applies on transferable securities as defined by MiFID. Second, the PD establishes two import thresholds:

- article 1(2)h: securities included in an offer where the total consideration for the offer in the EU is less than 5 million EUR, calculated over a period of 12 months, are outside of the scope of the $\mathrm{PD}$;

- article 3(2)e: offers a total consideration below 100.000 EUR, calculated over a period of 12 months, are excluded from the obligation to publish a prospectus;

- that implies that Member States are free to regulate the obligation to publish a prospectus of offers where the total consideration is between 100.000 EUR and 5 million EUR (over 12 months) at their own discretion.

Third, the PD article 3(2) constitutes certain exemptions from the obligation to publish a prospectus, such as: (i) an offer is addressed only to 'qualified investors' (under MiFID); (ii) an offer is addressed to fewer than 150 natural or legal persons per Member State other than 'qualified investors', (iii) an offer of securities of minimum 100.000 EUR per each investor; and (iv) an offer of securities worth at least 100.000 EUR per security.

If we take into consideration the typical operational and business models of crowdinvesting platforms, i.e. mainly the equity-based crowdfunding, we see that the following features are relevant and typical for crowdinvesting:

- as was mentioned above, typical funds raised range between 100.000s EUR to several million EUR;

- typical investors are unprofessional clients;

- typical investors invest up to several thousands EUR, way below 100.000/investor or security;

- crowdinvesting opportunities often take form of instruments other than MiFID securities/instruments; if platforms opt for MiFID license to obtain single passport rule benefits, they may lose certain market segments as a result.

Disclosure requirements in relation to prospectus of offers below 5 million EUR (and of at least 100.000 EUR) are left to the discretion of respective Member States. In fact, these regimes vary significantly among Member States. In Slovakia, basically the same regime as over 5 million EUR

24 EUROPEAN COMMISSION: Communication From The Commission To The European Parliament, The Council, The European Economic And Social Committee And The Committee Of The Regions Unleashing the potential of Crowdfunding in the European Union $/ *$ COM/2014/0172 final $* /$

25 Directive 2003/71/EC of the European Parliament and of the Council of 4 November 2003 on the prospectus to be published when securities are offered to the public or admitted to trading and amending Directive 2001/34/EC (further as „PD“). 
offers applies, whereas the National Bank of Slovakia has a discretionary power to lower the requirements in individual cases. ${ }^{26}$ French regulation is more flexible as it allows for "light-prospectus" to be issued for offers of up to 1 million EUR over 12 months. The light-prospectus is supposed to give simple, clear and balanced information on the specific features of the project and the type of offering, which could be rationally expected as a solid industry standard nonetheless. ${ }^{27}$ Similarly, Austria requires a simplified prospectus for offers between 250.000 EUR and 5 million EUR offers. ${ }^{28}$ In Spain, a specific crowdfunding regulation limits the size of offers to 2 million EUR per project per platform per year, or 5 million EUR if the offer is directed exclusively to accredited investors. The issuers are not required to publish prospectus in such cases. ${ }^{29}$ Several other Member States have put forward custom regulation of the crowdfunding or crowdinvesting with specific rules governing the obligations to publish prospectus. As of now, it is clear that offers between 100.000 EUR and 5 million EUR have varying and incomparable regimes within the EU; in fact 17 Member States require a prospectus below the 5 million EUR threshold. ${ }^{30}$

The Commission's recent initiative for legislative proposal of Prospectus Regulation replacing the PD puts forward an exemption for the smallest capital raisings from the prospectus obligation, "under the premise that imposing an EU-prospectus for offers of securities to the public of a consideration below EUR 500,000 (as is often the case on crowdfunding platforms) is disproportionately costly in relation to the envisaged proceeds of the offer." ${ }^{31}$ It is also required that Member States refrain to impose disclosure requirements that would be disproportionate or unnecessary burden in relation to such offers.

The Commission's Impact Assessment based the proposal of increasing the lower limit of 100.000 EUR to 500.000 EUR on the research suggesting that the average fund raising campaign on crowdfunding platforms in the EU was worth around 220.000-250.000 EUR. ${ }^{32}$ This finding appears to be obsolete and contradictory to the other sources used by the Commission just recently, stating the average amount at around 500.000 EUR. ${ }^{33}$ The Impact Assessment mentions other options that were considered by the Commission as a way of supporting growing crowdfunding market without endangering the consumers' rights, such as increasing the amount of non-qualified investors without triggering the obligation to publish a prospectus. The Commission's approach to regulating the minimum prospectus obligations also takes into consideration the total potential amount of raised

26 Sec. $125 \mathrm{~h}(3)+125 \mathrm{~h}(4)$ of the Act no. 566/2001 Col. on Securities and Investment Services as amended.

27 Authorité des Marchés Financiers' instruction on investor information to be provided by the issuer and crowdfunding investment advisers or investment services providers within the framework of a crowdfunding offering (DOC-2014-12). Various AMF decrees, orders, instructions and ordinances regulate this; available at: <http://www.amf-france.org/en_US/ Acteurs-et-produits/Prestataires-financiers/Financement-participatif---crowdfunding/Cadre-reglementaire.html>

28 The Alternative Financing Act 114/2015. Available at:

<https://www.ris.bka.gv.at/GeltendeFassung.wxe?Abfrage=Bundesnormen\&Gesetzesnummer=20009241>

29 Article 68(2) and 83(1)b of the Law 5/2015 of 27 April on Promoting Business Finance. Available at: <https://www.boe. es/buscar/doc.php?id=BOE-A-2015-4607>

30 Proposal for a Regulation Of The European Parliament And Of The Council on the prospectus to be published when securities are offered to the public or admitted to trading. COM/2015/0583 final - 2015/0268 (COD).

31 EUROPEAN COMMISSION: Commission Staff Working Document: Crowdfunding in the EU Capital Markets Union, Brussels, SWD(2016) 154 final. 6.

32 EUROPEAN COMMISSION: Commission Staff Working Document Impact Assessment Accompanying the document Proposal for a Regulation of the European Parliament and of the Council on the prospectus to be published when securities are offered to the public or admitted to trading. SWD/2015/0255 final - 2015/0268 (COD).

33 EUROPEAN COMMISSION: Commission Staff Working Document: Crowdfunding in the EU Capital Markets Union, Brussels, SWD(2016) 154 final. 10. 
retail money, though not absolutely, since the $\mathrm{PD}$ never meant to impose any limits on the amount of individual investors' investments. It is therefore conceivable that even under current PD regime millions of EUR could be fundraised without appropriate disclosure. Most of the Member States' bespoke regulation of crowdfunding takes a different approach and aims at higher 'de minimis' limits combined with relatively low maximum amounts of individual investor's investments (typically in thousands of EUR/campaign). The Commission's proposal is nevertheless a step forward, though it may have been advisable to adopt a more straightforward approach to supporting the harmonization of crowdfunding markets and adopting structural limits on the individual investors' investments while allowing companies to raise funds of up to 1.000.000-2.000.000 EUR without undergoing the prospectus obligation. As of now, it is clear that Member States' discretion does not lead to comparable regimes and therefore the development of the EU-wide crowdfunding market may be hindered as a result.

\section{$3 \quad$ CONCLUSION}

In the paper, we briefly discussed the requirements and needs of equity-based crowdfunding. We mentioned several identified barriers that hinder the development of crowdfunding markets, while it is also necessary to account for specific risks related to this novel means of finance, primarily for SMEs. One of the critical points in developing the crowdfunding regulation is to admit that the actual EU capital markets regulation was not prepared with crowdfunding in mind. Therefore the regulation has not yet developed responses suitable for the online, almost frictionless and borderless, phenomenon of crowdfunding. One such example is the obligation to publish a prospectus, which leaves the harmonizing potential for better coherence of crowdfunding markets unmet, in its actual and also revised versions. The discretionary power of states in terms of regulating the offers between 500.000 EUR to 10 million EUR under the new Prospectus Regulation leaves huge room for unpredictability and incompatibility of respective Member States' regimes. It does not encourage the single market in one of its most smooth conduits, natural to crowdfunding: the internet economy.

\section{Bibliography:}

AGRAWAL, A. - CATALINI, C. - GOLDFARB, A.: Entrepreneurial Finance and the Flat-World Hypothesis. Evidence from Crowd-Funding Entrepreneurs in the Arts, 2010. Working papers.

AUTHORITÉ DES MARCHÉS FINANCIERS. Instruction on investor information to be provided by the issuer and crowdfunding investment advisers or investment services providers within the framework of a crowdfunding offering (DOC-2014-12). Available at:

$<$ http://www.amf-france.org/en_US/Acteurs-et-produits/Prestataires-financiers/Financement-participatif---crowdfunding/Cadre-reglementaire.html>.

EUROPEAN COMMISSION: Commission Recommendation of 6 May 2003 concerning the definition of micro, small and medium-sized enterprises (Text with EEA relevance) (notified under document number C(2003) 1422). OJ L 124, 20.5.2003, p. 36-41.

EUROPEAN COMMISSION: Commission Staff Working Document Impact Assessment Accompanying the document Proposal for a Regulation of the European Parliament and of the Council on the prospectus to be published when securities are offered to the public or admitted to trading. SWD/2015/0255 final - 2015/0268 (COD). 
EUROPEAN COMMISSION: Commission Staff Working Document: Crowdfunding in the EU Capital Markets Union, Brussels, SWD(2016) 154 final. 10.

EUROPEAN COMMISSION: Communication From The Commission An action plan to improve access to finance for SMEs $/ *$ COM/2011/0870 final */.

EUROPEAN COMMISSION: Communication from the Commission to the Council, the European Parliament, the European Economic and Social Committee and the Committee of the Regions - "Think Small First" - A "Small Business Act” for Europe $\{\operatorname{SEC}(2008) 2101\}\{\operatorname{SEC}(2008) 2102\} / *$ COM/2008/0394 final*/.

EUROPEAN COMMISSION: Communication From The Commission To The European Parliament, The Council, The European Economic And Social Committee And The Committee Of The Regions Unleashing the potential of Crowdfunding in the European Union $/{ }^{*}$ COM/2014/0172 final */.

DE BUYSERE, K. - GAJDA, O. - KLEVERLAAN, R. - MAROM, D.: A Framework for European Crowdfunding, 2012.

Directive 2003/71/EC of the European Parliament and of the Council of 4 November 2003 on the prospectus to be published when securities are offered to the public or admitted to trading and amending Directive 2001/34/EC.

Directive 2004/39/EC of the European Parliament and of the Council of 21 April 2004 on markets in financial instruments amending Council Directives 85/611/EEC and 93/6/EEC and Directive 2000/12/EC of the European Parliament and of the Council and repealing Council Directive 93/22/EEC.

EDWARDS, T. - DELBRIDGE, R. - MUNDAY, M.: Understanding innovation in small and medium-sized enterprises: a process manifest. In: Technovation, 2005, 25, 10, p. 1119-1127.

ESMA. “Opinion. Investment-based crowdfunding. ESMA/2014/1378.” 2014, p. 5.

FREEDMAN, D. M. - NUTTING, M. R.: A Brief History of Crowdfunding. Including Rewards, Donation, Debt, and Equity Platforms in the USA, 2015. Available at: <http://www.freedman-chicago.com/ec4i/History-of-Crowdfunding.pdf $>$.

GRIFFIN, Z.: Crowdfunding. Fleecing the American masses. In: Case Western Reserve Journal of Law, Technology $\&$ the Internet, 2012. Available at

$<$ http://ssrn.com/abstract=2030001 $>$.

MUlLER, P. - CALIANDRO, C. - GAGLIARDI, D. - MARZOCCHI, C.: Annual report on European SMEs 2014/2015. Brussels: European Commission, 2015, p. 4-8.

ORDANINI, A. - MICELI, L. - PIZZETTI, M. - PARASURAMAN, A.: Crowd-funding. transforming customers into investors through innovative service platforms. In: Journal of Service Management, 2015, 22, 4, pp. 443-470. DOI 10.1108/09564231111155079.

PES, G. N. - PORRETTA, P.: Microfinance, EU Structural Funds and Capacity Building for Managing Authorities. A Comparative Analysis of European Convergence Regions. Houndmills: Palgrave Macmillan, 2015, p. 11-23.

Proposal for a Regulation Of The European Parliament And Of The Council on the prospectus to be published when securities are offered to the public or admitted to trading. COM/2015/0583 final - 2015/0268 (COD).

SUNSTEIN, C. R. - HASTIE, R.: Wiser: Getting Beyond Groupthink to Make Groups Smarter. N.p.: Harvard Business Review, 2014.

The Act no. 566/2001 Col. on Securities and Investment Services as amended. Slovakia.

The Alternative Financing Act 114/2015. Austria. Available at:

$<$ https://www.ris.bka.gv.at/GeltendeFassung.wxe?Abfrage=Bundesnormen\&Gesetzesnummer=20009241>.

The Law 5/2015 of 27 April on Promoting Business Finance. Spain. Available at:

<https://www.boe.es/buscar/doc.php?id=BOE-A-2015-4607>. 


\section{Contact information:}

Mgr. Ján Mazúr

jan.mazur@flaw.uniba.sk

Comenius University in Bratislava, Faculty of Law,

Department of Financial Law

Šafárikovo nám. 6

81000 Bratislava

Slovak Republic 